\title{
Capital Market Contagion in the Stock Markets of Visegrád Countries Based on the Heckman Selection Model*
}

\author{
Máté Csiki - Gábor Dávid Kiss
}

In our study, we examine contagions materialising between the stock market indices of three countries in the Visegrád region - Poland, Czech Republic, Hungary - and selected developed countries - USA and Germany. The sample covers the period between 1997 and 2017, which includes a number of events that caused major financial and capital market turbulences in past decades, the effects of which are still significant on the capital markets of the Visegrád region today. We simulated the comovement of Visegrád and developed markets with a DCC procedure, and applied the Heckman selection model - a novel technique in relevant studies - to explain the volatility of the correlation and to capture collective behaviours between the markets. Our analysis of the extreme returns of regional indices reveals increasing global integration across the regional equity markets and their exposure to the oil market. The relevance of our work is confirmed by the presence of contagions - as presented within the framework of the model - between the regional indices and the S\&P500 as well as the DAX index which are caused by financial and capital market shocks, while there is also evidence of a significant impact exerted by the German stock market index on the Visegrád stock indices. Periodically and as a function of market shifts, some variance can be observed in the contagion channels, and the unique properties specific to the region can be recognised.

Journal of Economic Literature (JEL) codes: G15, C33, F65

Keywords: contagion, Heckit, equity market

\section{Introduction}

In recent decades, more and more emphasis has been placed on recognising and addressing shocks related to deepening global financial and capital market

\footnotetext{
* The papers in this issue contain the views of the authors which are not necessarily the same as the official views of the Magyar Nemzeti Bank.

Máté Csiki is PhD Student at the Faculty of Economics of the University of Szeged.

E-mail: csiki.mate@eco.u-szeged.hu

Gábor Dávid Kiss is habil PhD, Associate Professor at the Faculty of Economics of the University of Szeged.

E-mail: kiss.gabor.david@eco.u-szeged.hu

This research was supported by the project EFOP-3.6.2-16-2017-00007, entitled Aspects on the development of intelligent, sustainable and inclusive society: social, technological, innovation networks in employment and digital economy. The project has been supported by the European Union, co-financed by the European Social Fund and the budget of Hungary.
}

The Hungarian manuscript was received on 26 February 2018.

DOI: http://doi.org/10.25201/FER.17.4.2352 
integration, the spread of financial innovations and global liquidity flows. Along with theories focusing on fundamental-based contagion, arguments emphasising financial and capital market relationships as key contagion channels have increasingly come into focus (Király et al. 2008). The external financial adjustment of small, open economies across Europe took place rapidly; the resilience of the economies to external financial shocks improved after the financial crisis of 2008-2009 (Magas 2018). Analyses breaking away from fundamentals with a new focus on financial market relationships increasingly came to the foreground in the aftermath of the "devastating crises" of the past two decades, emphasising shocks stemming from abrupt changes in capital flows and the importance of highleverage finance. Stability may be upset by temporary disturbances arising from global financial imbalances and sudden shifts in liquidity flows. All of this can be traced back to the development of network structures across capital markets and the resulting collective behaviour exhibited in relation to extreme events.

The study examines contagions materialising between the stock market indices of three countries in the Visegrád region ${ }^{1}$ (V3: Poland, Czech Republic, Hungary) and selected developed countries (the USA and Germany). In order to avoid the bias stemming from its lower level of liquidity, the Slovakian stock market is not included in the sample. The review covers the period between 1 January 1997 and 8 September 2017. The sources of weekly data are stooq.pl and the "ARAD" database of the Czech National Bank.

First, we used a dynamic conditional correlation (DCC) model to analyse the dynamic conditional comovement of regional and developed stock market indices. Then, with the assistance of the financial market variables applied, we attempted to explain the volatility of the comovement simulated by the DCC model by running the Heckman selection model - a novel technique in relevant studies - with special regard to detecting contagions unfolding around extreme events. The results of the Heckman model point to the presence of contagions arising from shocks between developed and regional markets and the financial market variables applied in the model suggest possible descriptions for the correlation change. In addition to the presence of contagions, it is important to highlight the time profile of the changes in possible causal channels and their diverging effects amid extreme negative and extreme positive returns.

Following a presentation of the empirical antecedents affecting the region, we discuss collective capital market behaviour and provide an overview of the relevant literature, with special regard to the presentation of capital market contagions. After describing the model and methodology applied in the research, we then analyse the comovement between regional and developed markets and give an overview

\footnotetext{
${ }^{1}$ For the rest of the article we refer to these countries as "V3" on numerous occasions.
} 
of the extremities of the Visegrád stock market indices. The article concludes with a description of the results received after running the Heckman panel regression, first for the entire review period of 1997-2017 and subsequently, after dividing the period into three parts in accordance with the attribute of ascending depression, for the resulting three periods.

\section{Theoretical overview}

For the interpretation of the results, we need to present the empirical antecedents of covariance analyses affecting the Central and Eastern European region and the manifestations of the consequences of capital market complexity and collective behaviour in money market contagions, divergence and interdependency.

\subsection{Empirical background}

Gelos - Sahay (2000) studied financial market spillovers on the stock prices of the V3 economies. Starting from 1993, financial market integration increased significantly, especially during the period of the 1998 Russian crisis. The authors found that the Hungarian equity market has the largest exposure and the Czech equity market had the smallest exposure to the contagion emanating from the Russian crisis, which is also confirmed by Schotman - Zalewska (2006) in relation to the 1997 crash in Asia and the 1998 Russian crisis. Cappiello et al. (2006) referred to an increasing degree of integration from the 2000s in the V3 countries. Correlation of the V3 with the German and American markets increased substantially during the 2007-2008 subprime crisis, which is consistent with the research of Syllignakis - Kouretas (2011), who estimated a rise in the correlation coefficient from 0.5 to 0.75 during the crisis with the use of a DCC model. The heightened volatility observed during crisis periods is accompanied by a rise in dynamic conditional correlation coefficients, which may serve as evidence for financial market contagions between V3 and developed (German and US) markets. Baumöhl et al. (2011) found that correlation between the markets ranged between 0.5 and 0.7 on average, with significant outliers around the crisis periods.

Pukthuanthong - Roll (2009) measured the integration between the V3 and developed markets by the degree of determination by global factors. They found that stock market prices in Visegrád countries can be significantly explained by global factors from the 1990s, which points to a high level of integration. Gilmore et al. (2012) found evidence of long-run cointegration between the V3 and German equity markets.

Wang-Moore (2008) investigated comovement between the three emerging Central and Eastern European stock markets with the euro area market over a sample period from 1994 to 2006 by utilising a DCC model. The correlation coefficient ranged between 0.3 and 0.5. The authors also observed that the Asian and Russian crises and EU accession strengthened the level of integration. Savva and Aslanidis (2010) 
also relied on a DCC model to measure the degree of correlation between the V3 and the euro area and demonstrated that the Polish and Czech markets increased their correlation to the euro area from 1997 to 2008, whereas for the Hungarian market the correlation, although high, remained constant. The integration between the $\mathrm{V} 3$ and the euro area increased over time, especially after EU entry, and remained strong even during the subprime crisis (Gjika-Horvath 2012).

In summary, we can conclude that the events of the past few decades strengthened the integration between the V3 and developed markets significantly (Baumöhl Lyócsa 2014). EU accession negotiations and the efforts of V3 countries to bring their regulatory framework and legal standards in line with European Union directives improved investors' confidence. Improvements in stock exchange operations and trading regulations, accession to the EU, intensification of foreign investments and capital inflows and more flexible exchange rate regimes across the region all contributed to the increase in the region's comovement with developed markets. The subprime crisis, crisis management and the European debt crisis raised the Visegrád region's level of integration even further. In addition, the European Union adopted the IFRS standards, which also determine the consolidated reporting obligations of listed companies. According to a Hungarian survey, publicly traded companies also pay special attention to convincing stakeholders because - in addition to the statutorily prescribed content - they provide a considerable amount of voluntary disclosures (Kovács 2015), which assists in gaining and retaining the confidence of investors.

\subsection{Definition of collective behaviour and its presence in the relevant literature}

According to Bonanno et al. (2001), the complex interpretation of capital markets has three consequences. On the one hand, price returns and volatility are only asymptotically stationary, while the autocorrelation of returns is monotonously decreasing for at least twenty trading days. On the other hand, a high degree of cross correlation may exist between different sets of time series. This leads to the third level of complexity, which points to the existence of a type of collective behaviour in capital markets during extreme market events. In capital markets, collective behaviour manifests itself in contagions, interdependence and divergence.

Based on Kiss (2017), three levels can be distinguished in the definition of contagion. With respect to contagion according to the narrowest definition of the term that we used for the purposes of this study, we observed significantly increased correlation in turbulent periods compared to calm periods. In our study, we divided $\mathbb{H}$ capital market returns into two - an $\mathbb{N}$ normal and an $\mathbb{X}$ extreme - sets, where the $\mathbb{H}=\mathbb{N} \cup \mathbb{X}$ correlation holds true. The $n$ index included in the definitions denotes normal, whereas the $x$ index denotes extreme V3 stock market returns. $m_{i}$ refers to regional indices, while $m_{j}$ refers to developed indices. 
Definition: Capital market contagion is understood as a significant increase in the $\rho^{m_{i}, m_{j}}$ correlation between $m_{i}$, and $m_{j}$ markets under extreme returns in the Visegrád markets (Kiss 2017):

$$
\rho_{n}^{m_{i j} m_{j}}<\rho_{x}^{m_{i j} m_{j}}
$$

Accordingly, if weekly returns in the $m_{i}$ market are divided according to normal and extreme returns, we will observe a significantly higher correlation between the $m_{i}$, and $m_{j}$ markets under extreme returns $\left(\rho_{x}^{m_{i}} m_{j}\right)$.

Király et al. (2008) identify financial and capital market relationships as key contagion channels. Studying the 1997 crisis in the Far-East and the 1998 crash in Russia, Van Royen (2002) asserts that the propagation of contagion does not depend on the macroeconomic fundamentals of the given country. A number of studies pointed out that amidst sharply declining and volatile stock prices, shocks induce a significant increase in the comovement of equity markets (Campbell et al. 2002; Lin et al. 1994). The 1998 rouble crisis drew attention to high-leverage financing as a possible cause of contagion; the global liquidity shortage gave rise to financing problems, and high-leverage funds withdrew simultaneously from geographical regions which were apparently not related in any way (Király et al. 2008). Wong - Li (2010) observed that a disruption in the balance of global capital flows triggers capital flights on a global scale, while the market comovements generated by the shock considerably hampers the basic function of diversification, i.e. the effectiveness of risk spreading.

In studying contagions, it is important to highlight the phenomenon of herding, especially when fundamentals cannot fully explain the shocks emerging in the financial system and their spillover. Herding behaviour occurs when market participants excessively imitate the behaviour of others, which may contribute to the persistence of asset price bubbles or even fuel further price inflation (Lakos Szendrei 2017). The increasing financial openness and the intensifying liberalisation of capital flows often entail rapid shifts in short-term capital movements (Magas 2010). Indeed, globalisation mitigates the need for the gathering of country-specific information; investors define the balance between portfolio diversification and costly additional information gathering themselves (Magas 2010). This also puts homogenisation into the foreground. Syllignakis - Kouretas (2011) provided an empirical verification of the herding behaviour relevant to the region when, in relation to the subprime crisis, they emphasised the herding observed in the Central and Eastern European region.

Using wavelet analysis, Dewandaru et al. (2018) investigated the evidence of contagion between the stock market indices of Germany, France, the United Kingdom, Sweden and Switzerland in the context of the great crises of the past decades, along with a number of factors of the intensifying financial integration that 
exacerbate external vulnerability. The authors found that prior to the US subprime crisis, contagions generated only short-term shocks in the markets under review. They underpinned the role of the French, German and British markets in the spread of the crisis, while calling attention to the extreme strength of the contagion effects in the case of the 2008-2009 crisis and the European sovereign debt crisis, where signs of contagion appeared in all index-pairs.

Over the longer term, within fundamental linkages, market comovements tend to reflect real economic embeddedness (Chen - Zang 1997), whereas global factors appear to be the driving force behind short-term fluctuations (Van Royen 2002). In the case of strong linkages between two economies, an interdependence can be observed in stable periods, whereas significantly increased correlations around shocks signal the presence of contagion (Forbes - Rigobon 2002). The close economic ties of Central and Eastern European countries with Germany strongly determine the magnitude of dynamic conditional correlations. European stock market indices are far more likely to correlate with German indices than with the US indices, while an extreme rise in the US DJI index provides evidence of interdependence between the V3 indices and the DAX index (Kiss 2017). Wang et al. (2017) found evidence of interdependence between the US-Chinese, US-Japanese and US-Russian capital markets in the context of the US subprime crisis. In order to interpret these events, we need to clarify the concept of interdependence, i.e. a manifestation of collective behaviour beyond contagion.

Definition: In the case of capital market interdependence, the $\rho^{m_{i} m_{j}}$ correlation between $m_{i}$, and $m_{j}$ markets does not change significantly under extreme returns in the Visegrád markets (Kiss 2017):

$$
\rho_{n}^{m_{i}, m_{j}} \approx \rho_{x}^{m_{i}, m_{j}}
$$

Accordingly, if weekly returns in the $m_{i}$ market are divided according to normal and extreme returns, we will not observe a significantly different correlation between the $m_{i}$, and $m_{j}$ markets under extreme returns $\left(\rho_{x}^{m_{i}} m_{j}\right)$.

In response to the crisis, there is evidence of significantly decreasing comovement in the case of US, EMU, Polish, Hungarian and Czech 10-year bond yields (Kiss - Kosztopulosz 2012). Farkas (2011) pointed out that the Visegrád countries constitute an unique economic model. Investors view countries with similar properties homogeneously, based on such properties as geographical location, economic structure, history or credit rating. In the case of shocks, investors seek to simultaneously shed from their portfolios all assets that are regarded as homogenous. As a previously homogeneous region collapses as a result of this heterogenisation, this process appears as capital market divergence (Bearce 2002).

Definition: When capital market divergence occurs, there is a significant decline in the $\rho^{m_{i}, m_{j}}$ correlation between $m_{i}$, and $m_{j}$ markets under extreme returns in the Visegrád markets (Kiss 2017): 


$$
\rho_{n}^{m_{i}, m_{j}}>\rho_{x}^{m_{i}, m_{j}}
$$

Accordingly, if weekly returns in the $m_{i}$ market are divided according to normal and extreme returns, we will observe a significantly lower correlation between the $m_{i}$, and $m_{j}$ markets under extreme returns $\left(\rho_{x}^{m_{i}} m_{j}\right)$.

\section{Methodology}

We used a dynamic conditional correlation (DCC) model to analyse the dynamic conditional comovement of regional and developed stock market indices. We sorted the extreme returns of the V3 indices by a VaR (Value-at-Risk) procedure and then tried to explain the volatility of the comovement under extreme returns by running the two-step Heckman panel regression with the help of the variables applied. For our calculations we utilised Matlab R2014a and the Gretl software package.

\subsection{DCC-GARCH (dynamic conditional correlation)}

Generalised ARCH, i.e. GARCH (Generalised Autoregressive Conditional Heteroscedasticity) models are key tools in addressing the problems arising from autoregression and heteroscedasticity. In the $\operatorname{GARCH}(p, q)$ model $p$ and $\varepsilon^{2}$ define the lookback period of the error term, while $q$ and $\sigma^{2}$ define the lookback period of the standard deviation; $\alpha_{i}$ denotes the effect of present news on conditional variance, while $\beta_{i}$ denotes the persistence of volatility; i.e. the shock exerted by new information on old information (Kiss 2017):

$$
\sigma_{t}^{2}=\omega+\sum_{i=1}^{p} \alpha_{i} \varepsilon_{t-i}^{2}+\sum_{i=1}^{q} \beta_{i} \sigma_{t-i}^{2}
$$

Defining the $\alpha_{1}$ and $\beta_{1}$ parameters in the case of $\operatorname{GARCH}(1,1)$ models is of crucial importance. The baseline $\operatorname{GARCH}(1,1)$ model assumes that present volatility is a function of past volatility and returns and that there is no difference between the market responses to positive and negative information shocks.

In order to provide evidence of collective behaviours on financial and capital markets, we need to verify temporal changes in correlations, for which it is indispensable to observe the time factor and to strip out heteroscedasticity from the changes in comovements. The dynamic conditional correlation (DCC) model is suitable for this exercise.

Based on Engle (2002), the dynamic conditional correlation model (DCC model) simulates the conditional $\sigma_{i, t}^{2}$ variance of time series that can be characterised with $r_{t} \| \phi_{t-1} \sim N\left(0, H_{t}\right)$ return and all $\phi_{t-1}$ information available at $t-1$ point in time:

$$
\left[\begin{array}{cc}
\sigma_{i, t}^{2} & \sigma_{i, j, t} \\
\sigma_{i, j, t} & \sigma_{j, t}^{2}
\end{array}\right]=\sum_{i=1}^{p} \alpha_{i, j}\left[\begin{array}{cc}
e_{i, t-p}^{2} & e_{i, j, t-p} \\
e_{i, j, t-p} & e_{j, t-p}^{2}
\end{array}\right]+\sum_{i=1}^{q} \beta_{i, j}\left[\begin{array}{cc}
\sigma_{i, t-q}^{2} & \sigma_{i, j, t-q} \\
\sigma_{i, j, t-q} & \sigma_{j, t-q}^{2}
\end{array}\right]
$$




\subsection{Extreme price movements}

Kiss - Varga (2016) observed that extreme events can be removed by means of parametric (statistical) or non-parametric approaches. The statistical approach assumes that the dataset is characterised by some probability distribution (e.g. normal distribution), and removes $(\mathbb{X})$ outliers on this basis. For our purposes, we applied the VaR calculated from the conditional volatility received from the fitting of the GARCH model, a method widely used for risk perception in financial and capital markets. Assuming a normal distribution, extreme returns $\left(r_{X V a R}\right)$ under the $\mathrm{VaR}$ model comprise logarithmic price fluctuations at a probability level below 5 per cent. In this case, returns are considered extreme where with a probability of 95 per cent they fall farther than within a standard deviation of 1.65 from the expected assumed value of zero (Madura 2008). That is,

$$
r_{X V a R+}>\mu+1,65 \cdot \sigma_{t} \quad \text { and } \quad r_{X V a R-}<\mu-1,65 \cdot \sigma_{t} \text {, }
$$

assuming that $\mu \cong 0$ and that conditional volatility is $\sigma_{t}$.

\subsection{Heckman selection model}

We examined the volatility of the comovement between Central and Eastern European and developed stock price indices and the appearance of collective behaviours with the Heckman selection model (Heckman 1976). The method removes extreme return values from the time series, and describes the factors that trigger extreme returns of the variables that might cause extremities (7). The model is suitable to observe the collective behaviour that occurs in financial and capital markets. A significantly deviating value of the constant $\left(\beta_{1}\right)$ received from the regression equation (9) may point to contagion or divergence, while a significantly non-deviating value of the constant may signal interdependence, in consideration of the strength and sign of the coefficients and the value of the explanatory variables. The regression equation of the model (9) is capable of capturing the factors influencing the volatility of the comovement between developed and V3 markets $\left(X_{i}^{\prime}\right)$, as well as their direction and the magnitude of their impact $\left(\beta_{i}\right)$. The coefficient of the variables shows in which direction and to what extent a given variable influences the dynamic conditional correlation under an extreme negative and extreme positive yield environment of the V3 indices. The model is based on a two-step regression: the first step is the selection mechanism that sorts and explains tail events ( $Z^{*}=1$ cases). The second step is a regression model which explains the drivers of the fluctuations in the comovement of V3 and developed market with the assistance of variables incorporated into the model that prevail under tail events.

Selection mechanism (step 1):

$Z_{i}^{*}=w_{i}^{\prime} \gamma+u_{i} ; Z_{i}=1$ if $Z^{*}>0$, otherwise $0 ;$ where $Z_{i}=1$ denotes extreme returns,

$$
\operatorname{Prob}\left(Z_{i}=1 \mid w_{i}\right)=\phi\left(w_{i}^{\prime} \gamma\right) \text { and } \operatorname{Prob}\left(Z_{i}=0 \mid w_{i}\right)=1-\phi\left(w_{i}^{\prime} \gamma\right) \text {. }
$$


Regression model (2nd step):

$$
Y_{i}=X_{i}^{\prime} \beta+\varepsilon_{i} \quad Z_{i}=1, \text { where } Y_{i} \text { is the dynamic conditional correlation. }
$$

The error terms of the selection and regression equations $\left(u_{i}, \varepsilon_{i}\right)$ are independent and follow a bivariate normal distribution; moreover, we measure the $\rho$ correlation between the error terms $\left(\operatorname{corr}\left[u_{i}, \varepsilon_{i}\right]=\rho\right)$. If the value of the $\rho$ correlation is 0 , the $\beta$ coefficients of the OLS model are free from specification error, i.e. the model can be used. In that case, Heckman's $\lambda$ parameter will be significant and the results received can be interpreted within the framework of the model (Greene 2003:784, Formula 22-20; Wooldridge 2012).

\subsection{The model}

The selection mechanism of the Heckman selection model applied is constructed as follows, if $Z_{i, t}=1$ :

$$
Z_{i, t}=\alpha_{1}+\alpha_{2} \mathrm{SP} 500_{t}+\alpha_{3} \mathrm{LIBOR}_{t}+\alpha_{4} \mathrm{OiI}_{t}+u_{i, t},
$$

where $Z_{i, t}$ denotes the extreme returns of the three Visegrád indices, $S P 50 O_{t}$ is the US S\&P500 stock price index, LIBOR $R_{t}$ is the USD-denominated London interbank interest rate (LIBOR), and $\mathrm{Oil}_{t}$ is the logarithmic return of Brent crude oil. The second step of the Heckman selection model is the regression equation, if $Z_{i, t}=1$ :

$$
\begin{aligned}
& D C C_{i j, t}=\beta_{1}+\beta_{2} R_{i, t}+\beta_{3} R P_{E U i, t}+\beta_{4} R P_{U S i, t}+ \\
& \quad+\beta_{5} P_{i, t}+\beta_{6} I_{i, t}+\beta_{7} I_{D A X}+\beta_{8} I_{R T S t}+\varepsilon_{i j, t}
\end{aligned},
$$

where $D C C_{i j, t}$ is the dynamic conditional correlation of regional markets with developed markets, $i$ is the relevant V3 country and $j$ is the relevant developed country. $R_{i, t}$ is the logarithmic differential of the 1-month interbank rate (Bubor, Wibor, Pribor) of the Visegrád countries. $R P_{E U} i, t$ is the difference between the 1-month interbank interest rates of the Visegrád countries and the euro area, and $R P_{\text {US } i, t}$ is the difference between the V3 and the USD-denominated 1-month Libor. $P_{i, t}$ is the logarithmic return of the exchange rate of regional currencies against the US dollar, $I_{i, t}$ is the logarithmic return of the regional indices, $I_{D A X} t$ is that of the German DAX stock price index, and $I_{R T S}$ is that of the Russian RTS stock price index.

\section{Results}

This chapter presents the primary statistics of the variables, the comovement of the developed and Visegrád markets, the extreme returns of the V3 indices and the results of the Heckman selection model.

\subsection{Primary statistics}

The primary statistics of the variables are presented in Annex 1. The expected mean - a value around zero - assumed by the baseline model and low standard deviation 
hold true for each individual variable. In the case of the indices, we found negative asymmetry differing from zero. Of the $\mathrm{V} 3$ indices, the BUX and the PX exhibit more significant negative skewness. The asymmetry of the Russian RTS index deviates the least from the baseline model. The negative asymmetry suggests that negative exchange rate shocks occur at a higher rate on the equity markets. The presence of the depreciation process that mostly characterises the period causing a positive asymmetry is demonstrated by the skewness of the currencies against the US dollar. Regarding interest rates, an analysis of the third moment reveals substantial differences. Other than the Pribor, the asymmetry of interbank rates is negative. A kurtosis higher than three - fat tailedness - increases the relative frequency of extreme fluctuations. Fat tailedness held true for the return of all variables under review. On the whole, we can conclude that extreme returns are far more likely to occur than random movements in the case of the indices, exchange rates and oil prices, which is also confirmed by the hypothesis of normal distribution, rejected on the basis of the Jarque-Bera test. Based on the Ljung-Box test, the lack of autocorrelation does not hold true for a significant part of the returns. For most variables, the p-values of the ARCH-LM tests point to the homoscedastic nature of the returns. The logarithmic differentials of the time series are covariance stationary: in other words, the first and second moments of the time series do not explicitly depend on time. The application of panel regression requires stationary inputs; we employed the Im, Pesaran and Shin test (IPS) to test for panel stationarity. According to the test, the variables used in the model are stationary (Annex 2).

The means of the V 3 stock price indices' dynamic comovement with the DAX index exceed the corresponding values with the S\&P500. The comovement of all three Visegrád indices proved to be stronger with the German index than with the US index. The deviation of the comovements is stronger in the case of the Czech stock price index and weaker in the case of the Hungarian index (Annex 3 ).

\subsection{Dynamic conditional correlation of $\mathbf{V} 3$ and developed stock price indices}

From 1993, the comovement of regional financial markets with developed markets increased significantly, especially during the period of the 1998 Russian crisis (Gelos - Sahay 2000). A surge in the comovement of the three markets can be also observed during the dotcom crisis (Figures 1 and 2). Representing the euro area with the DAX index, Figure 2 demonstrates the assertion by Gjika - Horvath (2012), namely, that the integration between the V3 and the euro area increased significantly after EU accession and remained strong even during the subprime crisis. In the first half of the review period, the Czech PX index exhibited weaker correlation compared to the region, which can be attributed to heterogenisation. Starting from the end of the 1990s, the Czech Republic pursued a convincing monetary policy and successfully applied an inflation targeting system. Positive expectations regarding the country were significantly reinforced by the performance of the real economy and the country's stable currency, which functioned as a local safe haven. 


\section{Figure 1}

Dynamic conditional correlation of V3 indices with the S\&P500 (1997-2017)

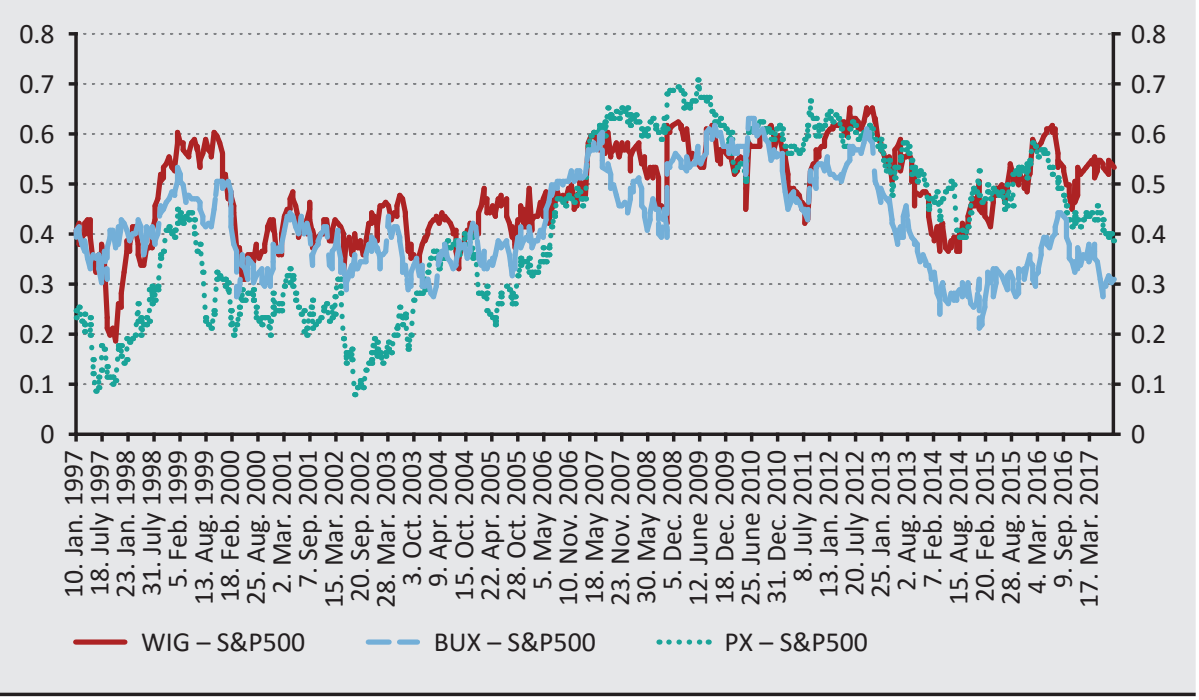

Figure 2

Dynamic conditional correlation of V3 indices with the DAX (1997-2017)

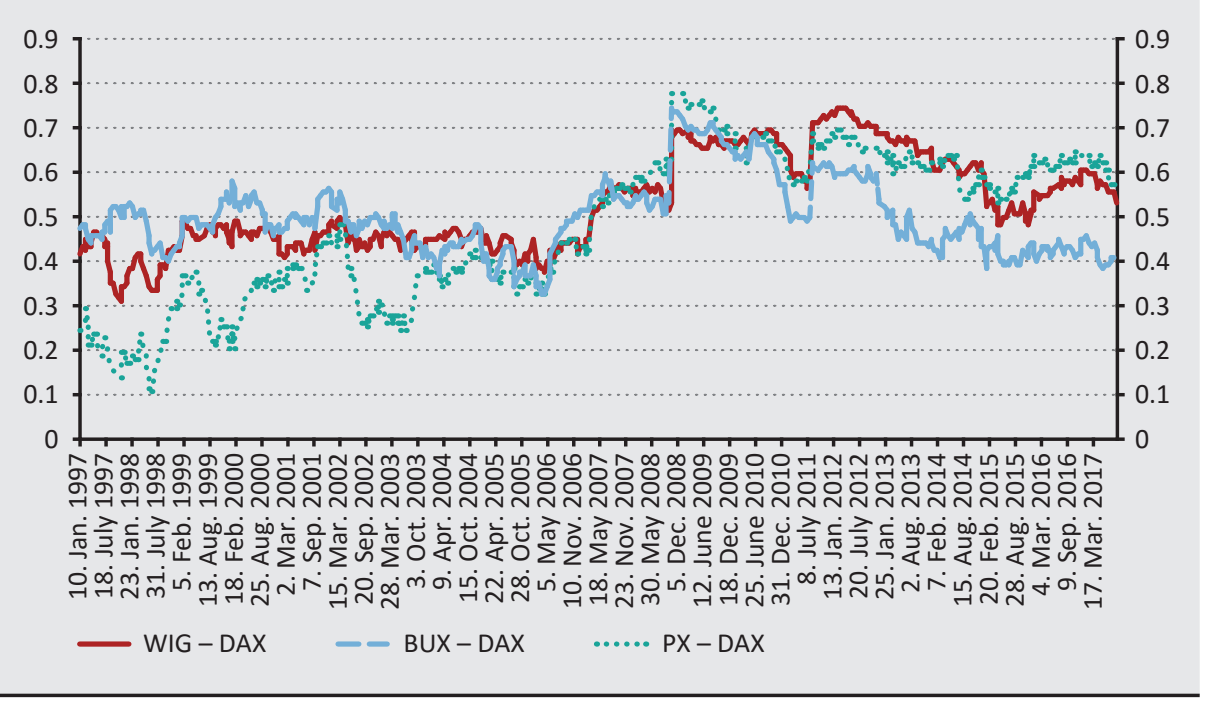


Demand and supply imbalances arising in the market of low-risk assets are among the reasons behind the global liquidity abundance of the first half of the 2000s. The emerging market crises of the 1990s and the dotcom crisis hitting developed markets were identified as the underlying factors of the imbalances, which led to a sharp increase in investors' demand for low-risk assets and the depletion of assets that were deemed to be low risk (Horváth - Szini 2015). Owing to the tighter monetary policies adopted in the mid-2000s in response to global excess demand and overheatedness, the V3 countries started to converge significantly to one another, and their correlation with the S\&P500 and DAX increased sharply. From 2006 until the outbreak of the crisis, the integration of regional markets and the DAX intensified. The comovement between regional markets and developed markets peaked in the period following the spillover of the crisis to Europe.

After the outbreak of the 2008 financial crisis, the correlations adjusted somewhat, but this process was associated with substantial volatility. The comovement between the markets intensified markedly during the shocks triggered by the European debt crisis, the Greek crisis and the South-European indebtedness. The correlation coefficients rose to the vicinity of the levels measured during the financial crisis, which may serve as evidence of the existence of contagion channels between the financial markets of the European Union. Similarly, comovement between regional markets and developed markets increased in response to the 2015 capital market shocks and uncertainty (turbulence on the Chinese stock exchange, Greek debt management problems).

\subsection{Extreme returns of Central and Eastern European indices}

It is also apparent in the V3 countries that extreme events are typically more likely to occur in the equity markets during turbulent periods. Regional extremities can be often characterised by the clustering of extreme events around significant crises and periods of capital market turbulence (Annex 4). Numerous extreme negative events were observed around the Asian and Russian crises at the end of the 1990s; however, the deepening capital market liberalisation of regional countries gave room for several extreme positive returns as well during the period. The effect of the dotcom crisis in the early 2000s and the global liquidity abundance that lasted until 2005 typically put extreme positive returns in the foreground. At the same time, as the analysis of extreme returns shows, even typically regional shocks (the terror attacks of 2001, the Uruguayan crisis, Venezuelan strikes or Mid-Eastern conflicts) also exerted a significant impact on the regional indices.

Extreme downward price shifts also form a cluster due to the monetary tightening measures of 2005-2006. The uncertain financial and capital market situation preceding the 2008 meltdown and the outbreak of the crisis generated negative returns in the V3 countries as well. Signs of some positive sentiment manifested themselves in capital markets in the second half of 2009, but this was interrupted 
from time to time by such events as the escalating European debt crisis, the Greek crisis and the increasing indebtedness of Southern European states. Negative returns also tended to occur more frequently during the periods of uncertainty caused by the faltering of the Chinese economy in 2015 and the persistent Greek crisis. In 2016 and 2017, the predominantly positive sentiment on the global markets prompted positive extreme returns in the Visegrád markets.

For the period as a whole, the procedure identified 92 extreme returns in the case of the BUX and the PX and 103 extreme returns for the WIG (Annex 5). The extreme returns had a higher percentage of negative returns. There are more extreme fluctuations in the returns of regional indices in the period preceding the 2008-2009 crisis (1997-2007) than in the post-crisis period (2009-2017). Unusual negative price shocks tended to dominate the crisis period of 2007-2009, while the number of unusual price increases was negligible.

\subsection{Heckman selection model}

This sub-chapter interprets the results from running the Heckman selection model. The first phase covers the period between 1997 and 2017. In the second phase, we divided the entire time series into three truncated time series: an optimistic period between 1997 and 2007, a crisis period between 2007 and 2009, and a period that lasted from 2009 to 2017.

\subsubsection{Heckman selection model - for the entire period}

Running the Heckman procedure for the entire period lasting from 3 January 1997 to 1 September 2017 yielded significant lambda values between the stock price indices of the developed countries and the Visegrád indices (Table 1). The results obtained can be interpreted in the context of the Heckman model for extreme positive and extreme negative movements in the Visegrád indices alike. 
Table 1

Result of the model for the whole period (1997-2017)

\begin{tabular}{|c|c|c|c|c|c|c|c|c|}
\hline \multirow{3}{*}{$\frac{\mathrm{Z}_{\mathrm{i}}}{\text { Variable }}$} & \multicolumn{4}{|c|}{ DCC-SP500-V3 } & \multicolumn{4}{|c|}{ DCC-DAX-V3 } \\
\hline & \multicolumn{2}{|c|}{ Extreme positive } & \multicolumn{2}{|c|}{ Extreme negative } & \multicolumn{2}{|c|}{ Extreme positive } & \multicolumn{2}{|c|}{ Extreme negative } \\
\hline & Coeff. & $p$ value & Coeff. & $p$ value & Coeff. & $p$ value & Coeff. & $p$ value \\
\hline constant & -1.9184 & $0.00^{* * *}$ & -1.7376 & $0.00^{* * *}$ & -1.9186 & $0.00^{* * *}$ & -1.7373 & $0.00^{* * *}$ \\
\hline SP500 & 11.6676 & $1.13 \mathrm{e}-09 * * *$ & -16.6209 & $8.03 \mathrm{e}-025 * * *$ & 12.2659 & $5.56 \mathrm{e}-011^{* * *}$ & -16.5308 & $1.33 \mathrm{e}-024^{* * *}$ \\
\hline LIBOR & -0.3223 & 0.7157 & 1.8518 & $0.0497^{* *}$ & -0.5779 & 0.4869 & 2.0597 & $0.0285^{* *}$ \\
\hline OIL & 2.9057 & $0.0019 * * *$ & -2.0260 & $0.0143^{* *}$ & 2.2891 & $0.0122^{* *}$ & -1.9565 & $0.0181^{* *}$ \\
\hline DCC $_{i j}$ & \multicolumn{2}{|c|}{ Extreme positive } & \multicolumn{2}{|c|}{ Extreme negative } & \multicolumn{2}{|c|}{ Extreme positive } & \multicolumn{2}{|c|}{ Extreme negative } \\
\hline Variable & Coeff. & $p$ value & Coeff. & $p$ value & Coeff. & $p$ value & Coeff. & $p$ value \\
\hline constant & 0.6422 & $0.00^{* * *}$ & 0.5746 & $0.00^{* * *}$ & 0.8079 & $0.00 * * *$ & 0.6335 & $0.00 * * *$ \\
\hline $\mathrm{R}_{\mathrm{i}}$ & 0.5189 & 0.1519 & -0.4373 & $0.0112^{* *}$ & 0.2457 & 0.5216 & -0.3339 & $0.0493^{* *}$ \\
\hline $\mathrm{RP}_{\mathrm{EU} \mathrm{i}}$ & -0.2112 & $0.0796 *$ & 0.0688 & $0.0633^{*}$ & -0.2497 & $0.0513^{*}$ & 0.0434 & 0.2376 \\
\hline $\mathrm{RP}_{\text {US } i}$ & -0.0442 & 0.605 & 0.0948 & 0.3171 & 0.0174 & 0.8471 & 0.0298 & 0.7486 \\
\hline $\mathrm{P}_{\mathrm{i}}$ & -1.5087 & $0.0138 * *$ & 0.9522 & $0.0202 * *$ & -1.1712 & $0.0582^{*}$ & 1.2943 & $0.0014^{* * *}$ \\
\hline $\mathrm{I}_{\mathrm{i}}$ & 0.193 & 0.6861 & -0.0913 & 0.7562 & -0.2759 & 0.5815 & 0.098 & 0.7367 \\
\hline $\mathrm{I}_{\mathrm{DAX}}$ & -0.1156 & 0.8388 & 0.1384 & 0.6217 & -0.0502 & 0.9256 & 0.0769 & 0.7792 \\
\hline $\mathrm{I}_{\mathrm{RTS}}$ & -0.2009 & 0.2966 & 0.2691 & $0.0801 *$ & -0.0149 & 0.9426 & 0.3029 & $0.0433^{* *}$ \\
\hline Lambda & -0.1158 & $0.0680 *$ & -0.0739 & $0.0189 * *$ & -0.1604 & $0.0006^{* * *}$ & -0.0666 & $0.0141^{* *}$ \\
\hline
\end{tabular}

Note: The selection mechanism is constructed as follows: $Z_{i, t}=\alpha_{1}+\alpha_{2} S P 50 O_{t}+\alpha_{3} L I B O R_{t}+\alpha_{4} \mathrm{Oil}_{t}+u_{i, t}$ where $Z_{i, t}$ denotes the extreme returns of the V3 index, $S P 50 O_{t}$ is the S\&P500 index, $L I B O R_{t}$ is the USD-denominated London interbank interest rate (LIBOR) and Oil t is the logarithmic return of Brent crude oil. The regression equation is $D C C_{i j, t}=\beta_{1}+\beta_{2} R_{i, t}+\beta_{3} R P_{E U i, t}+\beta_{4} R P_{U S i, t}+\beta_{5} P_{i, t}+\beta_{6} I_{i, t}+\beta_{7} I_{D A X}+$ $\beta_{8} I_{R T S t}+\varepsilon_{i j, t}$, where $D C C_{i j, t}$ is the dynamic conditional correlation of regional markets with developed markets, $i$ is the specific V 3 country and $j$ is the specific developed country. $R_{i, t}$ is the logarithmic differential of the 1-month interbank rate (Bubor, Wibor, Pribor) of the Visegrád countries. $R P_{E U} i, t$ is the difference between the 1-month interbank interest rates of the V3 and the euro area, and $R P_{U S} i, t$ is the difference between the V3 and the USD-denominated 1-month Libor. $P_{i, t}$ is the logarithmic return of the exchange rate of regional currencies against the US dollar, $I_{i, t}$ is the logarithmic return of the regional indices, $I_{\text {DAX }}$ is that of the German DAX stock price index, and $I_{R T S t}$ is that of the Russian RTS stock price index. If $p<0.1$ then $*, p<0.05^{* *}, p<0.01 * * *$.

Extreme events on Central and Eastern European stock markets

Based on the model, whenever comovements can be observed between the Visegrád indices and both developed markets similar factors affect the extreme positive and extreme negative movements in the regional indices. Of the variables included in the model, a robust shift in the S\&P500 index and oil price movements significantly influenced the extreme positive returns of the V3 indices, whereas extreme negative returns were also affected by the Libor, as the proxy variable for global risk.

Amid both positive and negative shocks, changes in the global investment environment - i.e. changes in the S\&P500 index - generate the same impact on Central and Eastern European stock price indices. Due to the significant exposure 
of the reviewed countries and indices to the oil market, oil price shocks exert a significant impact on the extreme fluctuations of stock price indices. The returns of regional indices move in the same direction in response to changes in global economic activity, which is consistent with the findings of Aloui et al. (2013). Through the discount factor effect, the intensification of global risks and an increase in discount rates on the corporate side may adversely affect stock prices (Jammazi et al. 2017). In the increasing interest environment of shock periods, investors may be nudged to the bond market and may reduce the share of stocks in their portfolios. As the inverse effect of rising interest rates, stock prices decline through the asset price channel (Baele et al. 2013).

The substantial effect of the three global variables on the shocks sustained by the regional stock price indices underpin the V3 indices' dependence on global factors as proposed by Pukthuanthong - Roll (2009). This demonstrates the broadbased global integration of the regional indices stemming from capital market liberalisation. Van Royen (2002) found that real economic integration is not fully determining in the case of short-term fluctuations. An extreme strengthening or weakening in the S\&P500 index triggers a shift in the same direction in regional markets, which may be evidence of financial contagion between the US and V3 stock price indices.

\section{Contagions}

Outlying constant values (significantly stronger dynamic conditional correlation) between developed and regional markets may signal contagions emerging in turbulent periods. The comovement constant of regional indices and the US index is 0.64 and it is 0.80 in the case of regional indices and the German index in an extreme positive return environment (Table 1). It should be noted, however, that constant values are influenced by the coefficient of the explanatory variables and by the values taken by the variables. In a positive return environment, the coefficients of the variables under review are negative; in other words, they reduce the value of the comovements. In an extreme negative return environment, the constants are 0.57 and 0.63 , i.e. their values are lower than in the case of extreme positive returns (Table 1). As opposed to the positive return environment, in a negative return environment the positive coefficient of most variables under review strengthens the degree of comovements further, as a function of the values taken by the variables. The average values of the explanatory variables may also differ as a function of market shifts. The higher the constant values with the German market, the closer the comovement of regional indices with the German market than with the US market, which is consistent with the empirical results so far. Chen and Zang (1997) pointed out that strong economic ties, as is the case between the Visegrád region and Germany, are a main determinant in the region. The study by Fałdziński et al. (2016) confirmed that the German, Polish, Hungarian and Czech capital markets are characterised by a similar long-term path. Gilmore et al. (2012) found evidence of 
long-run cointegration between the V3 and German equity markets. Over the long term, the direction of the money and capital markets of the Visegrád countries may be influenced by the German market.

Comovement under extreme positive returns

In the case of unusual strengthening, of the variables included in the model the Euribor risk premium and the exchange rate against the US dollar explain the changes in the comovement of developed markets and the Central and Eastern European indices (Table 1). Changes in the conversion rate vis-a-vis the US dollar have a stronger effect on the correlation between US and regional markets than between the German and the regional markets as opposed to the Euribor risk premium, the amplitude of which is stronger where there is a comovement with the German market.

Interest rates affect stock markets through numerous channels. On the one hand, the key policy rate influences stock prices through the portfolio rebalancing effect. On the other hand, stock prices also affect interest rates; an expected decline in stock prices signal pessimism regarding the future performance of the real economy, to which the monetary authority is expected to react with an interest rate cut (Jammazi et al. 2017). Besides inverse effects, effects may also be exerted in the same direction along the lines of the flight-to-quality strategy (Baele et al. 2013). Increasing regional risk premia may presage a surge in regional risk, which may precipitate a fall in stock prices. In the case of a jump in risk premia during turbulent periods investors try to shed riskier assets in line with the flight-to-quality strategy. As a result, less risky developed market assets are given priority, which may trigger capital outflows from emerging markets. According to the model, rising risk premia scale back the comovement between the developed and the Visegrád countries.

The relationship between the exchange rate and stock market returns can be approached from two sides. In line with the international trading effect, changes in the exchange rate affect equity prices (Aggarwal 1981). According to the theory of the portfolio balance effect, equity prices impact exchange rates (Bahmani-Oskooee - Sohrabian 1992). In boom periods the stock market is capable of inducing foreign capital inflows, which boosts demand for the local currency. In the model applied, changes in the exchange rate may exert an inverse effect on the comovement between the markets around positive capital market shocks. Weakening of the local currency against the US dollar reduces the comovement between the markets. In the model, global investment appetite increases under extreme positive returns, which may raise local stock price indices. Through the international trading effect, depreciation of the exchange rate exerts a positive effect on the competitiveness of export-oriented firms and improving export performance may in turn increase profits and hence, company value and stock prices (Aggarwal 1981). 


\section{Comovement under extreme negative returns}

In the case of a sharp fall in regional stock prices, the change in the comovement between developed and V3 indices may be explained by changes in the regional interest environment, the Euribor risk premium, the exchange rate and the Russian RTS index (Table 1). However, the Euribor risk premium had no effect on the correlation between the German and the V3 indices.

The improvement in the Visegrád interest environment observed around negative shocks may be a sign of a surge in regional risk. During shock periods, investors try to shed riskier assets, which may induce capital outflows both from emerging and developed equity markets, which in turn may explain the increased correlation between equity markets during volatile periods (Lin et al. 1994). According to the model, the comovement between developed and regional markets increases overall, but the rising interest environment reduces this effect somewhat. This effect is stronger between the S\&P500 and the regional indices. The Euribor risk premium exerts an inverse and weaker effect on dynamic comovement under negative extreme returns than in the case of extreme positive returns.

According to Table 1, changes in the exchange rate have a significant impact on comovements in volatile periods. Global investment appetite decreases while correlation between the markets increases in turbulent periods (Longin - Solnik 2001). Over the short term, depreciation generates a decline in the indices as it results in higher inflation expectations and consequently, investors become more sceptical about the future performance of the real economy (Ajayi - Mougoue 1996). In line with the international trading effect, changes in the exchange rate affect equity prices (Aggarwal 1981), the weak currency improves the competitiveness of export-oriented firms, which offsets expectations about the future performance of the economy. This effect can only take hold if demand for the products of export-oriented firms, i.e. the export markets, did not deteriorate. ${ }^{2}$ According to the model, in the case of extreme negative returns correlation ${ }^{3}$ between developed and Central and Eastern European markets is increased by a change in the exchange rate in the same direction. A change in the returns also affects the exchange rate: in periods of depression stock price declines lead to depreciation of the local currency. Deteriorating investor confidence may generate capital outflows in turbulent periods, which gives rise to depreciation of the local currency. The two effects may materialise concurrently in the financial and capital markets, and their opposing effects may simultaneously shape the relationship between stock prices and exchange rates (Tsai 2012). According to Dimitrova (2005),

\footnotetext{
${ }^{2}$ Due to the contraction in Western-European export markets in the wake of the 2008-2009 crisis, there was no sufficient demand for Central and Eastern European products; therefore, regional companies were unable to take full competitive advantage of the weakening local currency.

${ }^{3}$ This effect is stronger between the DAX and the regional indices.
} 
this effect may vary depending on the country and on the review period, which can be attributed to differences in capital mobility and the openness of capital markets and trading.

Examining the investor side, the value of international investments declines amid negative financial market shocks. On the one hand, this is because of the stock price effect and on the other hand, through the exchange rate effect a potential currency devaluation undermines the profitability of the positions accumulated so far. Weakening of the local currency may drive the indices into an adverse feedback loop, strengthening the already increased comovement even further.

In addition, it is important to highlight the significance of the Russian RTS index, which can be attributed to the important trade relations and financial ties between Russia and the Visegrád states. Wide-ranging real economic and financial relationships maintain potential contagion channels between the countries concerned. The effect of the Russian stock price index gains significance in the case of an unusual decline in the V3 stock price indices. ${ }^{4}$ According to the model, in extreme negative events the Russian RTS index may significantly influence the comovement between developed and regional indices.

\subsubsection{Heckman selection model - in optimistic periods and periods of depression}

In this sub-chapter, we analyse the entire review period divided into three phases along the lines of boom and depression periods. Drawing from the study by $\mathrm{Wu}$ and Lee (2015), based on the Visegrád stock price indices and applying flexible rules, we divided the entire time series into a boom period between 1997 and 2007, a period of depression between 2007 and 2009, and an optimistic period lasting from 2009 to 2017. In the case of the three fractional periods, we applied the extreme - normal return sorting (VaR procedure) pertaining to the entire review period.

In the first period - the period between 3 January 1997 and 2 March 2007 - the Visegrád states were characterised by increasing openness and accelerating capital market liberalisation. As the economies became increasingly open, their capital markets gradually integrated into the global capital flow chain in a declining interest environment with decreasing risk premia. They switched to more flexible exchange rate regimes and, thanks to the intensifying capital inflows, the period saw a continuous strengthening of the regional currencies (Novák 2014). Besides the "dirty float", the interest policy was given the important role of keeping the exchange rates within the desired bands (Neményi 2009). Owing to the shift in the demand function, oil prices rose continuously amid strong volatility during the period (Uliha 2016).

\footnotetext{
${ }^{4}$ It is perceived more strongly in the case of a comovement with the DAX index.
} 
During the global financial crisis that dominated the second period (9 March 2007 - 27 February 2009) the stability problems of regional countries and the contagion channels with developed markets were thrust to the foreground. The crisis prompted a sharp, sudden increase in the comovement between regional markets and developed countries. The spillover of the crisis inflicted serious damages to the stability of the financial systems of the regional countries. The 2008-2009 financial crisis and the warning signs of the impending crisis manifested themselves in the form of an extremely strong series of turbulences in the financial and capital markets of both the epicentre and the periphery. Running the two-step Heckman estimation procedure for the period 2007-2009 did not yield any significant result that could have been interpreted in the context of the model.

The third period lasting from 6 March 2009 to 1 September 2017 covers the period of post-crisis recovery and crisis management followed by the European debt crisis and subsequently, the period of global consolidation. Both the global economy and regional economies were characterised by a declining, near-zero interest environment and decreasing and realigning premia (Kosztopulosz 2012; Neményi 2009). The exchange rates of regional currencies exhibited gradual and at times drastic weakening. In the period of crisis management, oil prices began to climb gradually in response to specific demand shocks but later on - in the second half of 2014 - these specific shocks and technological innovations led to falling prices (Uliha 2016).

Analysing the dynamic conditional correlation of the S\&P500 and the V3 stock price indices for the truncated periods, running the Heckman panel regression yielded significant lambda values in the case of the extreme positive returns of the 1997-2007 period and in the case of the 2009-2017 period. Changes in the comovement of the German DAX index with regional indices can only be explained with the Heckman model in the case of the extreme positive returns of the 19972007 period.

Result of breaking down the time series into specific periods

Examining the comovement between regional indices and the US index, similar to the entire time series but to a lesser degree, a unidirectional change in the S\&P500 and oil prices strongly influenced the extreme rise in regional indices ${ }^{5}$ even in the pre-crisis period (Table 2). At the same time, in the post-crisis model changes in the US index and oil prices affected the extreme returns of the V3 indices to an extent that surpassed the degree observed in relation to the entire time series (Table 3). The strengthening of the influence of the US index indicates that global integration strengthened even further in the aftermath of the crisis. As a result of the US subprime crisis and its repercussions, the level of integration of regional

\footnotetext{
${ }^{5}$ Between the V3-DAX pair, the change in the S\&P500 index explains the regional extreme returns.
} 
markets increased further. With a stronger oil price coefficient, running the model for the period 2009-2017 demonstrates the continuously increasing exposure of the Central and Eastern European region to oil prices.

Once we examine the comovement between the V3 and S\&P500 indices in the context of the extreme strengthening episodes of the 1997-2007 period, we find that the value of the correlation constant pertaining to the period $(0.60)$ is lower than the corresponding value for the entire sample (0.64). ${ }^{6}$ However, as opposed to the total sample, in the pre-crisis model most variables have positive coefficients in extreme positive return environments.

\section{Table 2}

Result of the model for the pre-crisis period (1997-2007)

\begin{tabular}{|c|c|c|c|c|c|c|c|c|}
\hline & \multicolumn{4}{|c|}{ DCC-SP500-V3 } & \multicolumn{4}{|c|}{ DCC-DAX-V3 } \\
\hline$z_{i}$ & \multicolumn{2}{|c|}{ Extreme positive } & \multicolumn{2}{|c|}{ Extreme negative } & \multicolumn{2}{|c|}{ Extreme positive } & \multicolumn{2}{|c|}{ Extreme negative } \\
\hline Variable & Coeff. & $p$ value & Coeff. & $p$ value & Coeff. & $p$ value & Coeff. & $p$ value \\
\hline constant & -1.7246 & $0.00^{* * *}$ & -1.6274 & $0.00^{* * *}$ & -1.7162 & $0.00 * * *$ & -1.6283 & $0.00 * * *$ \\
\hline SP500 & 9.012 & $0.0006^{* * *}$ & -14.8280 & $2.67 \mathrm{e}-011^{* * *}$ & 9.3871 & $0.0001^{* * *}$ & -14.8884 & $1.23 \mathrm{e}-011^{* * *}$ \\
\hline LIBOR & -0.2734 & 0.914 & 1.979 & 0.3162 & -1.1244 & 0.6321 & 1.8482 & 0.3518 \\
\hline OIL & 2.8621 & $0.0026 * * *$ & -1.1038 & 0.3406 & 1.3212 & 0.1316 & -0.9546 & 0.9107 \\
\hline$D_{C C} j_{j}$ & \multicolumn{2}{|c|}{ Extreme positive } & \multicolumn{2}{|c|}{ Extreme negative } & \multicolumn{2}{|c|}{ Extreme positive } & \multicolumn{2}{|c|}{ Extreme negative } \\
\hline Variable & Coeff. & $p$ value & Coeff. & $p$ value & Coeff. & $p$ value & Coeff. & $p$ value \\
\hline constant & 0.606 & $0.00 * * *$ & 0.3887 & $0.00 * * *$ & 0.7083 & $0.00^{* * *}$ & 0.3886 & $0.00 * * *$ \\
\hline $\mathrm{R}_{\mathrm{i}}$ & 1.1935 & $0.0003^{* * *}$ & -0.2067 & 0.2958 & 0.6444 & $0.0515^{*}$ & -0.065 & 0.7147 \\
\hline $\mathrm{RP}_{\mathrm{EU} \mathrm{i}}$ & -0.1364 & 0.1435 & 0.0528 & $0.0800 *$ & -0.2204 & $0.0067^{* * *}$ & 0.1437 & 0.596 \\
\hline $\mathrm{RP}_{\text {US } \mathrm{i}}$ & -0.0638 & 0.2959 & 0.0036 & 0.9774 & 0.0041 & 0.9379 & -0.0948 & 0.4018 \\
\hline $\mathrm{P}_{\mathrm{i}}$ & -0.2030 & 0.7236 & 1.819 & $0.0017^{* * *}$ & 0.4695 & 0.3515 & 0.398 & 0.4424 \\
\hline$I_{i}$ & 1.0497 & $0.0158^{* *}$ & -0.5197 & $0.0557^{*}$ & 0.4346 & 0.2825 & -0.394 & 0.1028 \\
\hline $\mathrm{I}_{\mathrm{DAX}}$ & -0.6543 & 0.1186 & -0.2218 & 0.3982 & -0.3666 & 0.3408 & -0.0745 & 0.7501 \\
\hline $\mathrm{I}_{\mathrm{RTS}}$ & -0.1581 & 0.2662 & 0.1718 & 0.2069 & 0.0284 & 0.8501 & 0.2528 & $0.0368^{* *}$ \\
\hline Lambda & -0.1429 & $0.0003 * * *$ & -0.0358 & 0.4216 & -0.1612 & $2.87 \mathrm{e}-09 * * *$ & 0.0033 & 0.9107 \\
\hline
\end{tabular}

Note: For the explanation, see the Note to Table 1.

Apparently, the capital market integration of the region was weaker in the pre-crisis period. By contrast, when we examine the comovement between the V3 and the US markets, we find higher correlation constant values in the post-crisis period than for the entire sample. In the post-crisis model most explanatory variables have negative coefficients.

\footnotetext{
${ }^{6}$ The same is true for the DAX and V3 indices as well.
} 
As opposed to the total sample, in the pre-crisis period changes in the comovement between the Central and Eastern European indices and the US index were shaped by the interest environment of the V 3 and the interdependence of regional indices. ${ }^{7}$ The interest environment exerts an opposite effect than in the case of the extreme negative returns of the entire period. An analysis of the comovement between the V3 and the US market in the extreme positive return environment of the Visegrád region reveals that changes in interest rates had a dynamic effect on the comovement between the markets in the pre-crisis model, whereas changes in the exchange rate are among the determinants of the post-crisis model. In times of extreme strengthening, there is evidence of the herding behaviour across the Central and Eastern European region. In the region considered homogeneous by investors, the strengthening of an index or an increase in the comovement of an index with developed markets generates a similar effect even in relation to the rest of the regional indices. Similar to the pre-crisis period, the herding behaviour affecting the region can be also observed after the crisis, but in this case, it is triggered by negative shocks.

\section{Table 3}

Result of the model for the post-crisis period (2009-2017)

\begin{tabular}{|c|c|c|c|c|c|c|c|c|}
\hline \multirow{3}{*}{$\frac{\mathrm{Z}_{\mathrm{i}}}{\text { Variable }}$} & \multicolumn{4}{|c|}{ DCC-SP500-V3 } & \multicolumn{4}{|c|}{ DCC-DAX-V3 } \\
\hline & \multicolumn{2}{|c|}{ Extreme positive } & \multicolumn{2}{|c|}{ Extreme negative } & \multicolumn{2}{|c|}{ Extreme positive } & \multicolumn{2}{|c|}{ Extreme negative } \\
\hline & Coeff. & $p$ value & Coeff. & $p$ value & Coeff. & $p$ value & Coeff. & $p$ value \\
\hline constant & -2.1966 & $0.00 * * *$ & -1.8659 & $0.00 * * *$ & -2.2128 & $0.00 * * *$ & -1.9286 & $0.00^{* * *}$ \\
\hline SP500 & 15.6471 & $0.0006^{* * *}$ & -17.3024 & $3.87 e-08^{* * *}$ & 17.112 & $7.99 \mathrm{e}-05^{* * *}$ & -20.5061 & $2.82 \mathrm{e}-08^{* * *}$ \\
\hline LIBOR & -1.8024 & 0.4587 & -0.399 & 0.8114 & -2.0623 & 0.4631 & 2.1651 & 0.2916 \\
\hline OIL & 5.0798 & $0.0182^{* *}$ & -2.8876 & $0.0661^{*}$ & 4.5196 & 0.1713 & -2.7352 & 0.1393 \\
\hline$D_{C C} j_{j}$ & \multicolumn{2}{|c|}{ Extreme positive } & \multicolumn{2}{|c|}{ Extreme negative } & \multicolumn{2}{|c|}{ Extreme positive } & \multicolumn{2}{|c|}{ Extreme negative } \\
\hline Variable & Coeff. & $p$ value & Coeff. & $p$ value & Coeff. & $p$ value & Coeff. & $p$ value \\
\hline constant & 0.9362 & $0.00 * * *$ & 0.8647 & $0.00 * * *$ & 0.8459 & 0.1145 & 0.6042 & $0.00^{* * *}$ \\
\hline $\mathrm{R}_{\mathrm{i}}$ & 0.7082 & 0.3321 & 1.6782 & 0.1918 & 0.9074 & 0.2658 & -0.7242 & 0.6486 \\
\hline $\mathrm{RP}_{\mathrm{EU} \mathrm{i}}$ & -0.5075 & 0.5315 & -0.1262 & 0.2923 & -0.5256 & 0.5531 & -0.0982 & 0.4928 \\
\hline $\mathrm{RP}_{\text {US }} \mathrm{i}$ & -0.1071 & 0.705 & -0.2629 & 0.6561 & -0.0678 & 0.7904 & 0.5279 & 0.5192 \\
\hline $\mathrm{P}_{\mathrm{i}}$ & -2.4168 & $0.0683^{*}$ & -1.0905 & $0.0540^{*}$ & -2.0254 & 0.1445 & 0.1746 & 0.7742 \\
\hline $\mathrm{I}_{\mathrm{i}}$ & 0.4103 & 0.6841 & -1.5878 & $0.0041^{* * *}$ & 1.162 & 0.4855 & -0.2266 & 0.7307 \\
\hline $\mathrm{I}_{\mathrm{DAX}}$ & -1.3124 & 0.135 & 1.6657 & $0.0012^{* * *}$ & -0.4296 & $0.0381^{* *}$ & 0.6047 & 0.2728 \\
\hline $\mathrm{I}_{\mathrm{RTS}}$ & -1.4806 & $0.0032^{* * *}$ & 0.277 & 0.2988 & -1.4808 & $0.0126^{* *}$ & -0.4753 & $0.0776^{*}$ \\
\hline Lambda & -0.1771 & $0.0044^{* * *}$ & -0.1918 & $7.3 \mathrm{e}-013^{* * *}$ & -0.1203 & 0.4845 & -0.01218 & 0.7497 \\
\hline
\end{tabular}

Note: For the explanation, see the Note to Table 1.

${ }^{7}$ Changes in the comovement between the German DAX and regional indices can be explained by the interest environment and the Euribor risk premium. 
In the V3-S\&P500 relation, changes in exchange rates assume a prominent role in the post-crisis model. In this period, the respective currencies of all three Visegrád states depreciated significantly against the US dollar. A weak local currency may boost the competitiveness of export-oriented firms. However, even export markets contracted owing to the financial crisis and the protracted recovery in the euro area. Presumably, the fact that the exchange rate reduces comovement between the markets both in the case of a positive and a negative strengthening in regional indices can be attributed to the slow recovery in export competitiveness. The significant explanatory power of the Russian index underpins the important trade relations and financial ties between the Central and Eastern European region and Russia, which remained even after the crisis. Based on the model, there is evidence of the contagion effect generated by the underperforming RTS index, which can be attributed both to the Russian crisis in the 2010s and to the Russian sanctions. In addition, an examination of the comovement between the US and regional indices reveals the strong impact of the DAX stock price index in the extreme negative return environment of the region in the aftermath of the crisis. This confirms that the direction of the financial and capital markets of the Visegrád 3 is strongly influenced by the German market over the long term.

\section{Summary}

The selection mechanism of the Heckman model highlights the increasing global capital market integration of the Visegrád equity markets. The extreme positive returns of the V3 stock price indices were strongly shaped by global investment appetite (S\&P500 return) and global economic activity (oil price) variables. However, in an extreme negative return environment the effect of the global variables was stronger, and global risk (Libor) also became a contributor. Breaking down the time series into separate periods demonstrated that the region was characterised by a lower level of global integration preceding the 2008-2009 crisis, but the impact of global factors on the regional indices increased sharply following the crisis.

Based on the Heckman procedure applied for the purposes of this study, we can conclude that the correlation measured between the V3 and developed stock price indices is higher in the case of regional shocks, which points to the emergence of contagions between developed and regional markets. According to the results pertaining to the entire review period, fluctuations in the US S\&P500 have a significant impact on regional markets. However, the direction of the financial and capital markets of the Visegrád countries is strongly influenced by the German market, and strong economic ties and financial integration are important determinants in the region. Before the 2008-2009 subprime crisis there was a lesser degree of comovement between the regional indices and developed indices in turbulent periods, but the correlation proved to be stronger after the crisis. 
Periodically and as a function of market shifts, some variance can be observed in the contagion channels, and the unique properties specific to the region can be also recognised. With regard to the period as a whole, according to the model the volatility of the comovement between regional and developed markets may also be shaped by the regional interest rate environment, the Euribor risk premium, the exchange rate versus the US dollar and the Russian RTS index. According to the model applied, the comovement between the V3 and the US market in the extreme positive return environment of the Visegrád region was strongly influenced by changes in the interest rate in the pre-crisis period and by changes in the exchange rate in the post-crisis period. Further research is needed in order to identify the direction and effects of various contagion channels and to recognise the significance of the exchange rate.

We also found evidence of herding behaviour across the Central and Eastern European region, and the effect of homogenisation can be observed both before and after the crisis. In a region that is deemed homogeneous by investors, a shift in one of the indices or a change in its comovement with developed markets may nudge the rest of the regional indices in the same direction. The significance of the Russian RTS index across the entire time series and in the post-crisis model can be attributed to strong trade relations and financial ties between the $\mathrm{V} 3$ region and Russia, which may also exacerbate the spillover of shocks.

We should also call attention to the limitations of the Heckman selection model. In the case of a severe, systemic crisis - such as the 2008-2009 global financial crisis - the abovementioned ties cannot be measured by the method applied.

\section{References}

Aggarwal, R. (1981): Exchange Rates and Stock Prices: A Study of US Capital Market under Floating Exchange Rates. Akron Business and Economic Review, 3(9): 7-12.

Ajayi, R.A. - Mougoue, M. (1996): On the Dynamic Relation between Stock Prices and Exchange Rates. Journal of Financial Research, 19(2): 193-207. https://doi.org/ 10.1111/j.1475-6803.1996.tb00593.x

Aloui, R. - Hammoudeh, S. - Nguyen, D.K. (2013): A time-varying copula approach to oil and stock market dependence: The case of transition economies. Energy Economics, 39 (September): 208-221. https://doi.org/10.1016/j.eneco.2013.04.012

Baele, L. - Bekaert, G. - Inghelbrecht, K. - Wei, M. (2013): Flights to safety. NBER Working Paper Series, No. 19095: 1-51. https://doi.org/10.3386/w19095 
Bahmani-Oskooee, M. - Sohrabian, A. (1992): Stock Prices and the Effective Exchange Rate of the Dollar. Applied Economics, 24(4): 459-464. https://doi.org/ 10.1080/00036849200000020

Baumöhl, E. - Lyócsa, S. - Výrost, T. (2011): Shift contagion with endogenously detected volatility breaks: The case of CEE stock markets. Applied Economics Letters, 18(12): 11031109. https://doi.org/10.1080/13504851.2010.524610

Baumöhl, E. - Lyócsa, S. (2014): How smooth is the stock market integration of CEE-3? William Davidson Institute Working Paper, Number 1079. https://econpapers.repec.org/ paper/wdipapers/2014-1079.htm. Downloaded: 14 January 2018.

Bearce, D. (2002): Monetary Divergence: Domestic Policy Autonomy in the Post-Bretton Woods Era. University of Michigan Press, Ann Arbor.

Bonanno, G. - Lillo, F. - Mantegna, R. (2001): Levels of complexity in financial markets. Physica A: Statistical Mechanics and its Applications, 299(1-2): 16-27. https://doi.org/ 10.1016/S0378-4371(01)00279-5

Campbell, R. - Koedij, K. - Kofman, P. (2002): Increased Correlation in Bear Markets. Financial Analysts Journal, 58(1): 87-94. https://doi.org/10.2469/faj.v58.n1.2512

Cappiello, L. - Gérard, B. - Kadareja, A. - Manganelli, S. (2006): Financial integration of new EU member states. Working Paper Series No. 683, ECB. https://www.ecb.europa.eu/ pub/pdf/scpwps/ecbwp683.pdf?469b659d60f16ee2141bcb85eb0aa565. Downloaded: 20 January 2018.

Chen, N. - Zhang, F. (1997): Correlations, trades and stock returns of the Pacific-Basin Markets. Pacific-Basin Finance Journal, 5(5): 559-577. https://doi.org/10.1016/S0927538X(97)00022-X

Dewandaru, G. - Masih, R. - Masih, M. (2018): Unraveling the Financial Contagion in European Stock Markets During Financial Crises: Multi-Timescale Analysis. Emerging Markets Finance \& Trade, 54(4): 859-880. https://doi.org/10.1080/1540496X.2016.1266614

Dimitrova, D. (2005): The Relationship between Exchange Rates and Stock Prices: Studied in a Multivariate Model. Issues in Political Economy, 14: 1-25.

Engle, R.F. (2002): Dynamic Conditional Correlation - A Simple Class of Multivariate GARCH Models. Journal of Business and Economic Statistics, 20(3): 377-389.

Fałdziński, M. - Balcerzak, A. - Meluzín, T. - Pietrzak, M. - Zinecker, M. (2016): Cointegration of Interdependencies Among Capital Markets of Chosen Visegrad Countries and Germany. Mathematical Methods in Economics, Conference. 
Farkas, B. (2011): A piacgazdaság intézményrendszere az Európai Unió új tagállamaiban (Institutional system of the market economy in new European Union Member States). Statisztikai Szemle, 89(1): 50-76.

Forbes, J.K. - Rigobon, R. (2002): No contagion, only interdependence: measuring stock market comovements. Journal of Finance, 57(6): 2223-2261. https://doi. org/10.1111/0022-1082.00494

Gelos, G. - Sahay, R. (2000): Financial market spillovers in transition economies. Economics of Transition, 9: 53-86. https://doi.org/10.1111/1468-0351.00067

Gilmore, C.G. - Lucey, B.M. - McManus, G.M. (2012): The Dynamics of Central European equity market comovements. The Quarterly Review of Economics and Finance, 48(3): 605-622.

Gjika, D. - Horvath, R. (2012): Stock Market Comovements in Central Europe: Evidence from Asymmetric DCC Model. William Davidson Institute Working Papers, Series no. 1035, William Davidson Institute. University of Michigan.

Greene, W.H. (2003): Econometric Analysis. Prentice Hall. Pearson. New Jersey.

Heckman, J.J. (1976): The Common Structure of Statistical Models of Truncation, Sample Selection and Limited Dependent Variables and a Simple Estimator for Such Models. Annals of Economic and Social Measurement, 5(4):475-492.

Horváth, D. - Szini, R. (2015): The safety trap - the financial market and macroeconomic consequences of the scarcity of safe assets. Financial and Economic Review, 14(1): 111138. http://english.hitelintezetiszemle.hu/letoltes/5-horvath-szini-en.pdf

Jammazi, R. - Ferrer, R. - Jareno, F. - Hammoudeh, S. (2017): Main driving factors of the interest rate-stock market Granger causality. International Review of Financial Analysis, 52 (July): 260-280. https://doi.org/10.1016/j.irfa.2017.07.008

Király, J. - Nagy, M. - Szabó, E.V. (2008): Egy különleges eseménysorozat elemzése a másodrendü jelzáloghitel-piaci válság és (hazai) következményei (Analysis of a special sequence of events - the crisis on the secondary mortgage market and its consequences (also for Hungary)). Közgazdasági Szemle, 55 (July-August): 573-621.

Kiss, G.D. - Kosztopulosz, A. (2012): The impact of the crisis on the monetary autonomy of Central and Eastern European countries. Pénzügyi Szemle, 57(1): 27-51.

Kiss, G.D. - Varga, J.Z. (2016): Tőkepiaci idősorok extrém elmozdulásai (Extreme fluctuations in capital market time series). Statisztikai Szemle, 94(2): 162-182.

Kiss, G.D. (2017): Volatilitás, extrém elmozdulások és tökepiaci fertőzések (Volatility, extreme fluctuations and capital market contagion). JATEPress, Szeged. 
Kosztopulosz, A. (2012): A pénzügyi válság és következményei: monetáris politikai és szabályozási kihívások (The financial crisis and its consequences: Monetary policy and regulatory challenges). In: Farkas, B. (ed.): Válság: mérföldkő az európai integrációban? (Crisis: A milestone in European integration)? University of Szeged, Faculty of Economics, Szeged.

Kovács, Zs. (2015): Immaterial Assets in the Hungarian Accounting System and Financial Statements. Pénzügyi Szemle, 2015(2): 231-242.

Lakos, G. - Szendrei, T. (2017): Explanations of Asset Price Bubbles. Financial and Economic Review, 16(4): 122-150. http://doi.org/10.25201/FER.16.4.122150

Lin, W.L. - Engle, R.F. - Ito, T. (1994): Do bulls and bears move across borders? International transmission stock returns and volatility. Review of Financial Studies, 7(3): 507-538. https://doi.org/10.1093/rfs/7.3.507

Longin, F.M. - Solnik, B. (2001): Extreme correlation in international equity markets. Journal of Finance, 56(2): 649-676. https://doi.org/10.1111/0022-1082.00340

Madura, J. (2008): International Financial Management. Mason: Thomson.

Magas, I. (2010): Világgazdasági folyamatok és pénzügyi liberalizáció 1970-2010 (Global economic processes and financial liberalisation 1970-2010). MTA PhD Thesis. http://real-d. mtak.hu/521/1/tezisek.pdf. Downloaded: 1 March 2018.

Magas, I. (2018): Financial Adjustment in Small, Open Economies in Light of the "Impossible Trinity" Trilemma. Financial and Economic Review, 17(1): 5-33. http://doi.org/10.25201/ FER.17.1.533

Neményi, J. (2009): A monetáris politika szerepe Magyarországon a pénzügyi válság kezelésében (The role of monetary policy in Hungary's handling of the financial crisis). Közgazdasági Szemle, 56 (May): 393-421.

Novák, Zs. (2014): Monetáris politika, infláció és gazdasági növekedés Kelet-Közép- és Délkelet-Európában (Monetary policy, inflation and economic growth in Central and South Eastern Europe). Közgazdasági Szemle, 61 (July-August): 923-942.

Pukthuanthong, K. - Roll, R. (2009): Global market integration: An alternative measure and its application. Journal of Financial Economics, 94(2): 214-232. https://doi.org/10.1016/j. jfineco.2008.12.004

Savva, Ch.S. - Aslanidis, N. (2010): Stock market integration between new EU member states and the Euro-zone. Empirical Economics, 39(2): 337-351. https://doi.org/10.1007/s00181009-0306-6 
Schotman, P.C. - Zalewska, A. (2006): Non-synchronous trading and testing for market integration in Central European emerging markets. Journal of Empirical Finance, 13(4-5): 462-494. https://doi.org/10.1016/j.jempfin.2006.04.002

Syllignakis, M.N. - Kouretas G.P. (2011): Dynamic correlation analysis of financial contagion: Evidence from the Central and Eastern European markets. International Review of Economics and Finance, 20(4): 717-732. https://doi.org/10.1016/j.iref.2011.01.006

Tsai, I. (2012): The relationship between stock price index and exchange rate in Asian markets: A quantile regression approach. Journal of International Financial Markets, Institutions and Money, 22(3): 609-621. https://doi.org/10.1016/j.intfin.2012.04.005

Uliha, G. (2016): Oil and commodity markets' relationship with the macroeconomy. PhD Thesis, Corvinus University of Budapest. Online: http://phd.lib.uni-corvinus.hu/939/1/ Uliha Gabor.pdf. Downloaded: 11 December 2017.

Van Royen, A-S. (2002): Financial Contagion and International Portfolio Flows. Financial Analysts Journal, 58(1): 35-49. https://doi.org/10.2469/faj.v58.n1.2508

Wang, P. - Moore, T. (2008): Stock market integration for the transition economies: Timevarying conditional correlation approach. The Manchester School, 76(s1): 116-133. https://doi.org/10.1111/j.1467-9957.2008.01083.x

Wang, G-J. - Xie, C. - Lin, M. - Stanley, E. (2017): Stock market contagion during the global financial crisis: A multiscale approach. Finance Research Letters, 22 (August): 163-168. https://doi.org/10.1016/j.frl.2016.12.025

Wooldridge, J.M. (2012): Introductory Econometrics: A Modern Approach. Cengage Learning, Mason.

Wong, D.K.T. - Li, K-W. (2010): Comparing the Performance of Relative Stock Return Differential and Real Exchange Rate in Two Financial Crises. Applied Financial Economics, 20(1-2): 137-150. https://doi.org/10.1080/09603100903266468

Wu, S.J. - Lee, W.M. (2015): Intertemporal risk-return relationships in bull and bear markets. International Review of Economics \& Finance, 38 (July): 308-325. https://doi.org/ 10.1016/j.iref.2015.03.008 


\section{Annexes}

Annex 1: Primary statistics of the variables

\begin{tabular}{l|c|c|c|c|c|c|c|c}
\hline Variable & Mean & $\begin{array}{c}\text { Standard } \\
\text { deviation }\end{array}$ & Asymm. & Kurt. & $\begin{array}{c}\text { Norm. } \\
\text { distribu- } \\
\text { tion (JB) }\end{array}$ & $\begin{array}{c}\text { Autocorr. } \\
\text { (LB) }\end{array}$ & $\begin{array}{c}\text { Heterosc. } \\
\text { (ARCH- } \\
\text { LM) }\end{array}$ & $\begin{array}{c}\text { Stat. } \\
\text { (ADF) }\end{array}$ \\
\hline $\mathrm{I}_{\mathrm{BUX}}$ & 0.00 & 0.04 & -1.10 & 12.54 & 0 & 0.00 & 0.12 & 0 \\
\hline $\mathrm{I}_{\mathrm{WIG}}$ & 0.00 & 0.03 & -0.57 & 6.61 & 0 & 0.01 & 0.16 & 0 \\
\hline $\mathrm{I}_{\mathrm{PX}}$ & 0.00 & 0.03 & -1.07 & 14.00 & 0 & 0.00 & 0.22 & 0 \\
\hline $\mathrm{S} \& \mathrm{P500}$ & 0.00 & 0.02 & -0.76 & 9.39 & 0 & 0.00 & 0.09 & 0 \\
\hline $\mathrm{I}_{\mathrm{DAX}}$ & 0.00 & 0.03 & -0.62 & 7.46 & 0 & 0.17 & 0.46 & 0 \\
\hline $\mathrm{I}_{\mathrm{RTS}}$ & 0.00 & 0.06 & -0.32 & 7.86 & 0 & 0.00 & 0.11 & 0 \\
\hline $\mathrm{P}_{\mathrm{HUF}}$ & 0.00 & 0.02 & 0.43 & 5.55 & 0 & 0.72 & 0.85 & 0 \\
\hline $\mathrm{P}_{\mathrm{PLN}}$ & 0.00 & 0.02 & 0.77 & 7.40 & 0 & 0.09 & 0.38 & 0 \\
\hline $\mathrm{P}_{\mathrm{CZK}}$ & 0.00 & 0.02 & 0.25 & 4.06 & 0 & 0.54 & 0.64 & 0 \\
\hline $\mathrm{OIL}$ & 0.00 & 0.05 & -0.60 & 6.09 & 0 & 0.66 & 0.77 & 0 \\
\hline $\mathrm{R}_{\mathrm{HU}}$ & 0.00 & 0.04 & -3.65 & 82.88 & 0 & 0 & 0.17 & 0 \\
\hline $\mathrm{R}_{\mathrm{PL}}$ & 0.00 & 0.02 & -1.52 & 24.78 & 0 & 0 & 0.03 & 0 \\
\hline $\mathrm{R}_{\mathrm{CZ}}$ & 0.00 & 0.06 & 9.62 & 254.44 & 0 & 0 & 0.22 & 0 \\
\hline $\mathrm{R}_{\mathrm{US}}$ & 0.00 & 0.05 & -6.77 & 108.47 & 0 & 0 & 0.05 & 0 \\
\hline $\mathrm{R}_{\mathrm{EU}}$ & 0.00 & 0.11 & -1.55 & 104.82 & 0 & 0 & 0.20 & 0 \\
\hline $\mathrm{RP}_{\mathrm{EU}, \mathrm{HU}}$ & 0.00 & 0.06 & -5.45 & 197.63 & 0 & 0.65 & 0.97 & 0 \\
\hline $\mathrm{RP}_{\mathrm{US}, \mathrm{HU}}$ & 0.00 & 0.07 & 3.17 & 96.29 & 0 & 0.00 & 0.50 & 0 \\
\hline $\mathrm{RP}_{\mathrm{EU}, \mathrm{PL}}$ & 0.00 & 0.05 & 1.12 & 34.98 & 0 & 0.00 & 0.00 & 0 \\
\hline $\mathrm{RP}_{\mathrm{US}, \mathrm{PL}}$ & 0.00 & 0.14 & 3.29 & 182.11 & 0 & 0.00 & 0.67 & 0 \\
\hline $\mathrm{RP}_{\mathrm{EU}, \mathrm{CZ}}$ & 0.00 & 0.29 & -0.42 & 55.39 & 0 & 0.00 & 0.42 & 0 \\
\hline $\mathrm{RP}_{\mathrm{US}, \mathrm{CZ}}$ & 0.00 & 0.27 & 1.25 & 61.02 & 0 & 0.11 & 0.81 & 0 \\
\hline & & & & & & & &
\end{tabular}

Annex 2: Im, Pesaran and Shin test

\begin{tabular}{c|c}
\hline W statistics & -114.67 \\
\hline$p$ value of W & 0 \\
\hline Z statistics & -117.84 \\
\hline p value of Z & 0 \\
\hline Z DF statistics & -146.4 \\
\hline$p$ value of Z DF & 0 \\
\hline
\end{tabular}

Annex 3: First three moments of the dependent variables

\begin{tabular}{c|c|c|c}
\hline Variable & Mean & Standard deviation & Asymmetry \\
\hline $\mathrm{DCC}_{\mathrm{BUX}, \mathrm{PP} 500}$ & 0.42 & 0.09 & 0.34 \\
\hline $\mathrm{DCC}_{\mathrm{WIG}, \mathrm{PP} 500}$ & 0.48 & 0.09 & -0.31 \\
\hline $\mathrm{DCC}_{\mathrm{PX}, \mathrm{SP500}}$ & 0.42 & 0.17 & -0.17 \\
\hline $\mathrm{DCC}_{\mathrm{BUX}, \mathrm{DAX}}$ & 0.50 & 0.08 & 0.75 \\
\hline $\mathrm{DCC}_{\mathrm{WIG}, \mathrm{DAX}}$ & 0.53 & 0.11 & 0.34 \\
\hline $\mathrm{DCC}_{\mathrm{PX}, \mathrm{DAX}}$ & 0.48 & 0.17 & -0.22 \\
\hline
\end{tabular}




\section{Annex 4: Extreme returns of V3 indices (1997-2017)}

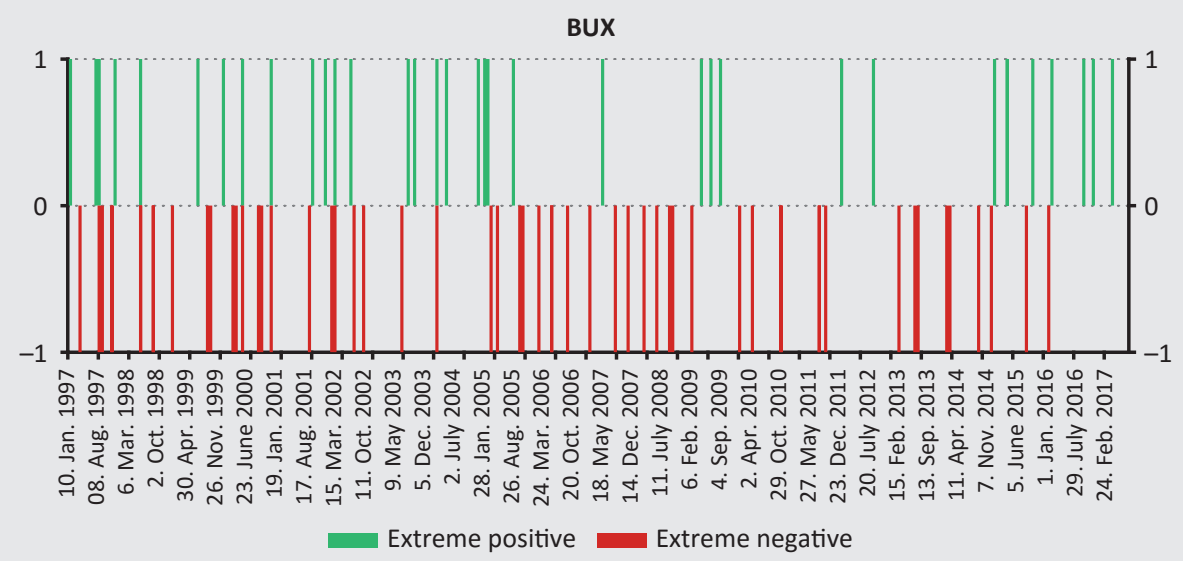

WIG

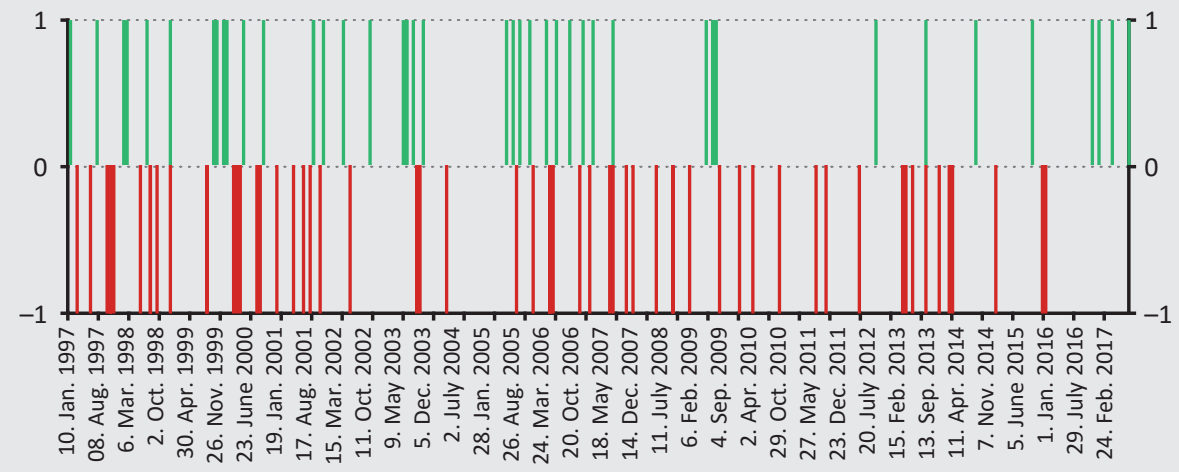

Extreme positive Extreme negative

PX

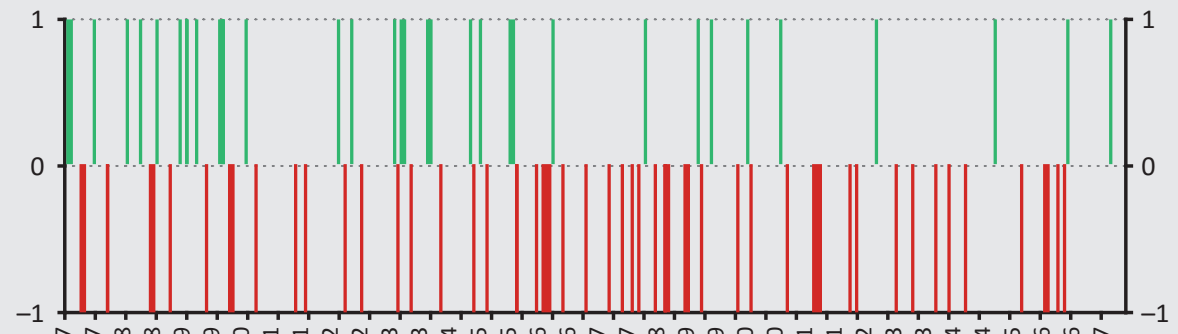

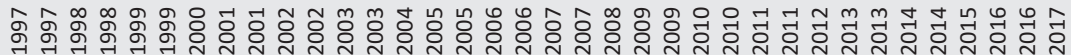

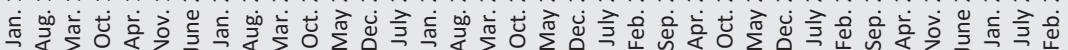

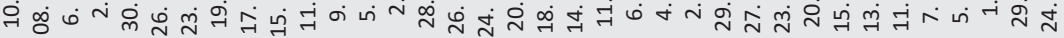

Extreme positive Extreme negative

Note: Results of the VaR procedure; the horizontal axis denotes trading weeks, on the vertical axis a value of 0 means normal returns, a value of 1 means extreme positive returns and a value of -1 means extreme negative returns. 
Annex 5: Occurrences of extreme and normal returns of V3 stock market indices

\begin{tabular}{l|c|c|c|l|c|c|c}
\hline 1997-2017 & BUX & WIG & PX & 2007-2009 & BUX & WIG & PX \\
\hline total return & 1,079 & 1,079 & 1,079 & total return & 105 & 105 & 105 \\
\hline "normal" return & 987 & 976 & 987 & “normal” return & 97 & 95 & 94 \\
\hline extreme return & 92 & 103 & 92 & extreme return & 8 & 10 & 11 \\
\hline \multicolumn{1}{c|}{ extreme positive } & 35 & 44 & 35 & extreme positive & 1 & 2 & 1 \\
\hline \multicolumn{1}{c|}{ extreme negative } & 57 & 59 & 57 & extreme negative & 7 & 8 & 10 \\
\hline 1997-2007 & BUX & WIG & PX & 2009-2017 & BUX & WIG & PX \\
\hline total return & 530 & 530 & 530 & total return & 444 & 444 & 444 \\
\hline "normal" return & 475 & 466 & 476 & "normal” return & 415 & 415 & 417 \\
\hline extreme return & 55 & 64 & 54 & extreme return & 29 & 29 & 27 \\
\hline \multicolumn{1}{c|}{ extreme positive } & 21 & 30 & 26 & extreme positive & 13 & 12 & 8 \\
\hline extreme negative & 34 & 34 & 28 & extreme negative & 16 & 17 & 19 \\
\hline
\end{tabular}

